\author{
PRIMARY: JURNAL PENDIDIKAN GURU SEKOLAH DASAR \\ VOLUME 10 NOMOR 6 DESEMBER 2021 \\ ISSN : 2303-1514 | E-ISSN : 2598-5949 \\ DOI : http://dx.doi.org/10.33578/jpfkip.v10i6.8637 \\ https://primary.ejournal.unri.ac.id/index.php/JPFKIP
}

\title{
PENGGUNAAN MEDIA AUDIO VISUAL DALAM PEMBELAJARAN MENYIMAK DIKELAS VI SEKOLAH DASAR
}

\author{
Jusmeri \\ Sekolah Dasar Negeri 006 Sungai Ara, Indragiri Hilir, Indonesia \\ Jusm3r1@gmail.com

\section{UTILIZING AUDIO-VISUAL MEDIA FOR TEACHING LISTENING AT GRADE VI ELEMENTARY SCHOOL}

\begin{tabular}{|c|c|}
\hline ARTICLE HISTORY & ABSTRACT \\
\hline $\begin{array}{l}\text { Submitted: } \\
17 \text { Oktober } 2021 \\
17^{\text {th }} \text { October } 2021\end{array}$ & $\begin{array}{l}\text { Abstract: Listening is one of the activities someone carries out to get and add new information } \\
\text { or new knowledge. In terms of listening, students tend to listen but do not understand the } \\
\text { content that is listened to. Students tend to underestimate listening, especially listening to } \\
\text { factual problems. One of the efforts that will be made to improve students' listening skills is to } \\
\text { use audio-visual media. The research used Classroom Action Research }(C A R) \text { using a research } \\
\text { design model of Kemmis and Mc. Taggart. This research was conducted at SD Negeri } 006 \\
\text { Sungai Ara. The subjects of this study were students of class VI (Six); the number of students } \\
\text { was } 24 \text {. Two cycles showed students' listening learning outcomes with an increasing average. } \\
\text { In the first cycle, the averages obtained before and after using audio-visual media were } 71.33 \\
\text { and } 76.63 \text {. In the second cycle, the averages obtained before and after using audio-visual } \\
\text { media were } 76.42 \text { and } 79.46 \text {. Thus, the application of audio-visual media improved students' } \\
\text { listening skills and students' learning interests. }\end{array}$ \\
\hline
\end{tabular}

Keywords: students, listening, audio-visual media

Accepted:

12 Desember 2021

$12^{\text {th }}$ December 2021

Published:

27 Desember 2021

$27^{\text {th }}$ December 2021
Abstrak: Menyimak merupakan salah satu aktivitas yang dilakukan oleh seseorang untuk mendapatkan dan menambah informasi baru atau pengetahuan baru. Siswa dalam hal menyimak, cenderung mendengarkan tetapi tidak memahami isi yang disimak. Siswa cenderung meremehkan pembelajaran menyimak khususnya menyimak persoalan faktual. Salah satu upaya yang akan dilakukan untuk meningkatkan keterampilan menyimak siswa yaitu dengan menggunakan media audio visual. Penelitian yang digunakan adalah Penelitian Tindakan Kelas (PTK) dengan menggunakan desain penelitian model Kemmis dan Mc. Taggart. Penelitian ini dilaksanakan di SD Negeri 006 Sungai Ara. Subjek penelitian ini adalah siswa kelas VI (Enam), jumlah siswa sebanyak 24 siswa. Dua siklus yang memperlihatkan hasil pembelajaran menyimak siswa dengan rata-rata yang meningkat. Siklus I rata-rata yang diperoleh sebelum dan sesudah menggunakan media audio visual yaitu 71.33 dan 76.63, sedangkan pada siklus II rata-rata yang diperoleh sebelum dan sesudah menggunakan media audio visual yaitu 76.42 dan 79.46. Penerapan media audio visual dapat meningkatkan kemampuan menyimak siswa dan daya tarik siswa terhadap pembelajaran.

Kata Kunci : siswa, pembelajaran menyimak, media audio visual

\section{CITATION}

Jusmeri. (2021). Penggunaan Media Audio Visual Dalam Pembelajaran Menyimak Di kelas VI Sekolah Dasar. Primary: Jurnal Pendidikan Guru Sekolah Dasar, 10 (6), 1683-1688. DOI: http://dx.doi.org/10.33578/jpfkip.v10i6.8637

\section{PENDAHULUAN}

Menyimak merupakan salah satu aktivitas yang dilakukan oleh seseorang untuk mendapatkan dan menambah informasi baru atau pengetahuan baru. Hal ini karena tujuan utama dari menyimak adalah memperoleh 
informasi yang disampaikan oleh orang lain. Dalam menyimak, terdapat proses besar mendengarkan, mengenal, serta menginterpretasikan lambang-lambang lisan (Tarigan, 2008). Dengan demikian, semakin sering seseorang menyimak maka semakin banyak pula informasi atau pengetahuan yang ia peroleh. Di sekolah dasar, pembelajaran menyimak sudah diberikan kepada siswa. Menyimak adalah suatu proses yang mencakup kegiatan mendengarkan bunyi bahasa, mengidentifikasi, menginterpretasi, menilai, dan mereaksi atas makna yang terkandung dalam bahan simakan. Menyimak melibatkan penglihatan, penghayatan, ingatan, pengertian, bahkan situasi yang menyertai bunyi bahasa yang disimakpun harus diperhitungkan dalam menentukan maknanya (Tarigan,1991).

Melalui wawancara dengan guru-guru yang mengajar kelas VI SDN 006 Sungai Ara diperoleh informasi bahwa siswa mengalami kesulitan pada mata pelajaran yang menganjurkan siswa-siswi untuk menyimak. Berdasarkan hasil observasi yang dilakukan, tampak bahwa siswa kurang fokus dalam memperhatikan apa yang disampaikan oleh guru, sehingga siswa mengalami kesulitan untuk mengetahui dan memahami materi yang disampaikan oleh guru mata pelajaran. Siswa dalam hal menyimak, cenderung mendengarkan tetapi tidak memahami isi yang disimak, siswa menganggap keterampilan menyimak itu mudah. Siswa cenderung meremehkan pembelajaran menyimak khususnya menyimak persoalan faktual.

Berdasarkan survey yang dilakukan di SDN 006 Sungai Ara Kabupaten Indragiri Hilir mengisyaratkan, bahwa saat ini dibutuhkan pembenahan serius dalam pembelajaran menyimak, karena menyimak juga mempengaruhi keberhasilan siswa dalam memahami materi pelajaran yang disampaikan oleh guru. Oleh karena itu, guru dituntut untuk kreatif dan inovatif serta memiliki kemampuan yang memadai dalam merancang pembelajaran menyimak, terutama berkaitan dengan media yang digunakan. Salah satu upaya yang akan dilakukan untuk meningkatkan keterampilan menyimak siswa yaitu dengan menggunakan media audio visual.

Menurut Briggs dalam Rudi dan Riyana (2009), bahwa media merupakan alat untuk memberikan perangsang bagi siswa dalam proses pembelajaran. Penggunaan media yang tepat dengan materi pembelajaran yang disampaikan dapat merangsang siswa untuk mampu mengikuti proses pembelajaran dengan baik. Media juga dapat meningkatkan motivasi belajar siswa, merangsang kegiatan belajar dan dapat meningkatkan kemampuan siswa terhadap informasi yang disimak. Salah satu media yang dapat digunakan dalam kegiatan menyimak adalah media audio visual.

Media audio visual merupakan media yang mempergunakan indera pendengar dan penglihatan. Media ini memberikan karakteristik pemanipulasian pesan hanya dilakukan melalui bunyi atau suara-suara. Media ini sangat cocok untuk kepentingan pengajaran bahasa (Mulyani, \& Permana, 1999). Sesuai dengan sifatnya, media audio visual memiliki banyak keunggulan dibandingkan dengan media lainnya. Media audio visual dapat membuat konsep yang abstrak menjadi lebih konkrit, dapat menampilkan gerak yang dipercepat atau diperlambat sehingga lebih mudah diamati, dapat menampilkan detail suatu benda atau proses, serta membuat penyajian pembelajaran lebih menarik, sehingga proses pembelajaran menjadi menyenangkan (Sriwidayah, 2017). Hal ini lah menjadi tujuan dalam penelitian ini untuk meningkatkan pembelajaran menyimak siswa-siswi dikelas menggunakan media audio visual di sekolah dasar.

\section{METODE PENELITIAN}

Jenis penelitian ini adalah Penelitian Tindakan Kelas (PTK) dengan menggunakan desain penelitian model Kemmis dan Mc. Taggart yaitu berbentuk spiral dari siklus yang satu ke siklus yang berikutnya. Setiap siklus meliputi planning (rencana), action (tindakan), observation (pengamatan), dan reflection (refleksi) (dalam Arikunto, 2002). 


\section{PRIMARY: JURNAL PENDIDIKAN GURU SEKOLAH DASAR \\ VOLUME 10 NOMOR 6 DESEMBER 2021 \\ ISSN : 2303-1514 | E-ISSN : 2598-5949 \\ DOI : http://dx.doi.org/10.33578/jpfkip.v10i6.8637 \\ https://primary.ejournal.unri.ac.id/index.php/JPFKIP}

Penelitian ini dilaksanakan pada bulan Januari sampai bulan Maret 2021. Subjek penelitian ini adalah peserta didik kelas VI SDN 006 Sungai Ara Kecamatan Kempas Kabupaten Indragiri Hilir, yang terdiri dari 24 peserta didik. Objek penelitian adalah peningkatan pembelajaran menyimak peserta didik. Teknik pengumpulan data menggunakan observasi dan wawancara. Instrumen yang digunakan tugas individu dalam mata pelajaran yang diajarkan. Data dianalisis secara kuantitatif dan disajikan dalam bentuk tabel.

\section{HASIL DAN PEMBAHASAN}

Pelaksanaan tindakan selama 2 siklus yang dilakukan sebanyak 12 kali pertemuan pada mata pelajaran Bahasa Indonesia, diperoleh data bahwa pembelajaran menyimak siswa mengalami peningkatan. Peningkatan pembelajaran menyimak mengalami peningkatan diketahui dengan menerapkan media audio visual.

\section{Pelaksanaan Siklus I}

Pada perencanaan tahap siklus I guru membuat perangkat pembelajaran berupa RPP, LKPD, dan Media Audio Visual yang memuat tindakanyang akan dilakukan dalam penelitian. Hal pertama yang peneliti lakukan sebelum melakukan tindakan, peneliti melakukan pelaksanaan pre tindakan dengan menggunakan tes uraian (asessment) atau tugas individu yang diberikan kepada siswa berkaitan dengan mata pelajaran Bahasa Indonesia. Sedangkan untuk pelaksanaan selanjutnya menggunakan media audio visual dan hasil pembelajaran menyimak sebelum dan sesudah menggunakan media audio visual dapat dilihat pada tabel berikut :

Tabel 1. Rekapitulasi Hasil Tes Pertemuan 1 s.d 6

\begin{tabular}{cccc}
\hline \multirow{2}{*}{ No } & \multirow{2}{*}{ Nama/Inisial } & Rata-rata Individu Kemampuan Menyimak Siswa \\
\cline { 2 - 4 } & Sebelum & Sesudah \\
\hline 1 & DF & 70 & 75 \\
2 & LG & 70 & 80 \\
3 & LL & 68 & 78 \\
4 & TR & 72 & 78 \\
5 & FSD & 70 & 75 \\
6 & ST & 75 & 75 \\
7 & RF & 77 & 78 \\
8 & WL & 70 & 75 \\
9 & AD & 68 & 80 \\
10 & HJ & 78 & 80 \\
11 & DT & 75 & 78 \\
12 & AY & 68 & 80 \\
13 & EC & 78 & 75 \\
14 & RD & 70 & 78 \\
15 & IS & 75 & 75 \\
16 & AN & 70 & 70 \\
17 & EV & 68 & 75 \\
18 & SH & 68 & 72 \\
19 & SF & 70 & 78 \\
20 & IMNI & 68 & 75 \\
21 & IK & 70 & 78 \\
22 & CH & 72 & $\mathbf{1 8 3 9}$ \\
23 & HJ & 72 & $\mathbf{7 6 . 6 3}$ \\
24 & AB & 70 & \\
\hline & Jumlah & $\mathbf{1 7 1 2}$ & $\mathbf{7 1 . 3 3}$ \\
\hline
\end{tabular}




\section{PRIMARY: JURNAL PENDIDIKAN GURU SEKOLAH DASAR \\ VOLUME 10 NOMOR 6 DESEMBER 2021 \\ ISSN : 2303-1514 | E-ISSN : 2598-5949 \\ DOI : http://dx.doi.org/10.33578/jpfkip.v10i6.8637 \\ https://primary.ejournal.unri.ac.id/index.php/JPFKIP}

Berdasarkan hasil tes menunjukan hasil pembelajaran menyimak siswa pada tes awal. Sebelum menggunakan media audio visual kemampuan menyimak siswa menunjukkan rata-rata kelas 71.33 , sedangkan setelah menggunakan media audio visual ratarata kelas meningkat menjadi 76.63 .

\section{Pelaksanaan Siklus II}

Pada perencanaan tahap siklus II guru membuat perangkat pembelajaran berupa RPP,
LKPD, dan Media Audio Visual yang memuat tindakanyang akan dilakukan dalam penelitian. Pada kegiatan siklus II dari pertemuan ketujuh sampai pertemuan dua belas. Sedangkan untuk pelaksanaan selanjutnya menggunakan media audio visual dan hasil pembelajaran menyimak sebelum dan sesudah menggunakan media audio visual dapat dilihat pada tabel berikut :

Tabel 2. Rekapitulasi Hasil Tes Pertemuan 7 s.d 12

\begin{tabular}{cccc}
\hline \multirow{2}{*}{ No } & Nama/Inisial & Rata-rata Individu Kemampuan Menyimak Siswa \\
\cline { 2 - 4 } & & Sebelum & Sesudah \\
\hline 1 & DF & 75 & 78 \\
3 & LG & 75 & 80 \\
4 & LL & 78 & 80 \\
5 & TR & 75 & 80 \\
6 & FSD & 78 & 85 \\
7 & ST & 75 & 80 \\
8 & RF & 77 & 80 \\
9 & WL & 78 & 78 \\
10 & AD & 78 & 78 \\
11 & HJ & 78 & 80 \\
12 & DT & 75 & 80 \\
13 & AY & 80 & 80 \\
14 & EC & 78 & 80 \\
15 & RD & 75 & 80 \\
16 & IS & 75 & 80 \\
17 & AN & 75 & 80 \\
18 & EV & 78 & 78 \\
19 & SH & 75 & 78 \\
20 & SF & 78 & 78 \\
21 & IMNI & 78 & 78 \\
22 & IK & 75 & 78 \\
23 & CH & 75 & 80 \\
24 & HJ & 75 & $\mathbf{7 9}$ \\
\hline & AB & 75 & $\mathbf{1 8 3 4}$ \\
\hline
\end{tabular}

Aktivitas siswa dalam kegiatan pembelajaran menyimak siswa menunjukan peningkatan yang signifikan dan mengalami peningkatan jika dibandingkan dengan siklus I. Berdasarkan hasil tes menunjukan pembelajaran menyimak siswa dengan ratarata 79.46 , sedangkan pada pembelajaran menyimak sebelum menggunakan media audio visual paad pertemuan 7 sampai dengan 12 menunjukkan peningkatan dari siklus I yang mana rata-rata kelas 76.42. Hal ini didukung dengan media audio visual, dengan adanya media pembelajaran menyimak ini siswa lebih fokus dan lebih memahami dalam menyimak materi yang diberikan.

\section{PEMBAHASAN}

Pada penelitian ini dilaksanakan tindakan pada masing-masing siklusnya yaitu, pada setiap siklus terdapat data mengenai perencanaan pembelajaran, pelaksanaan pembelajaran, hasil pembelajaran menyimak 
siswa dan respon siswa terhadap pembelajaran setelah diberikan media audio visual. Berdasarkan pengamatan pada siklus I pada pertemuan 1-6 terlihat bahwa guru melakukan perencanaan dengan membuat perangkat pembelajaran meliput RPP, LKPD, dan Media Pembelajaran. Dari tabel 1 diatas dapat dijelaskan jumlah nilai rata-rata kelas yang dilakukan penelitian sebelum dan sesudah menggunakan media audio visual, yang mana sebelum menggunakan media audio visual menunjukkan rata-rata kelas 71.33 dan sesudah menggunakan media audio visual menunjukkan rata-rata kelas 76.63 .

Berdasarkan hasil tes awal, maka peneliti perlu untuk mengadakan perbaikan kemampuan menyimak siswa dengan menggunakan media audio visual dengan intensitas lebih tinggi dibandingkan siklus I. Berdasarkan data hasil tes kemampuan menyimak siklus II yaitu dengan menggunakan media audio visual yang lebih intens diperoleh data rata-rata kelas adalah 79.46 , sedangkan yang sebelum menggunakan media audio visual menunjukkan rata-rata kelas 76.42. Hal ini menunjukkan adanya peningkatan terhadap kemampuan menyimak siswa dalam materi yang disampaikan oleh guru mata pelajaran.

Jalongo dalam Bingol (2014, hlm. 2)

"If we expect children to become good listeners, we will need to do more than worry, complain or demand. We need to teach them become active listeners". Jika kita mengharapkan siswa menjadi pendengar yang baik, maka kita harus mengajari mereka menjadi pendengar yang aktif. Penggunaan media audio visual dalam keterampilan menyimak terbukti mampu meningkatkan kemampuan menyimak siswa. Hal ini karena minat siswa untuk mengikuti pembelajaran menjadi lebih meningkat (Widyaningrum, 2016).

Manfaat dari penggunaan media ini diharapkan mampu menarik perhatian siswa dan memudahkan siswa dalam memahami materi. Pembelajaran akan memberikan hasil yang lebih baik jika didesain sesuai cara siswa belajar, bahwa kegiatan belajar adalah kegiatan yang aktif dimana siswa dapat membangun sendiri pengetahuannya, ini merupakan proses menyesuaikan konsep-konsep dan ide-ide baru dengan kerangka berfikir yang telah ada dalam pikiran mereka (Sohibun, 2017).

Hal ini perlu dikembangkan dan didukung oleh media pembelajaran salah satunya media audio visual yang mana dapat mengembangkan siswa dalam menyimak atau menganalisis lebih baik lagi dalam mencapai tujuan pembelajaran, selaras dengan penelitian Wijayakusuma (2009) yang menyatakan bahwa pengertian media adalah alat bantu apa saja yang dapat dijadikan sebagai penyalur pesan guna mencapai tujuan pembelajaran. Media audio visual memberikan banyak stimulus kepada peserta didik, karena sifat audio-visual/suara-gambar. Audiovisual memperkaya lingkungan belajar, memelihara eksplorasi, eksperimen dan penemuan, dan untuk mengembangkan pembicaraan dan mengungkapkan pikiranya (Purwono, \& Yutmini, 2014).

Sudjana dan Rivai dalam Daryanto (2013) menyatakan bahwa secara umum media mempunyai manfaat sebagai berikut: (a) pengajaran akan lebih menarik perhatian siswa sehingga dapat menumbuhkan motivasi belajar, (b) bahan pembelajaran akan lebih jelas maknanya sehingga dapat lebih dipahami oleh para siswa, dan memungkinkan siswa menguasai tujuan pembelajaran dengan lebih baik, (c) metode pembelajaran akan lebih bervariasi, tidak semata-mata komunikasi verbal melalui penuturan kata-kata oleh guru sehingga siswa tidak bosan dan guru tidak kehabisan tenaga dan, (d) siswa lebih banyak melakukan kegiatan belajar, sebab tidak hanya mendengarkan uraian guru, tetapi juga aktivitas lain seperti mengamati, melakukan, mendemonstrasikan dan lain-lain.

Meningkatnya daya tarik siswa dan hasil pembelajaran menyimak siswa ini tidak lepas dari peran media audio visual, dimana media audio visual merupakan media yang sangat efektif untuk pembelajaran individual maupun kelompok. Tidak hanya itu media audio visual memiliki kelebihan dapat diputar kembali, dipercepat ataupun diperlambat 
sesuai kebutuhan saat melakukan pembelajaran dikelas.

\section{SIMPULAN DAN SARAN}

Penerapan media audio visual berdasarkan hasil penelitian dan pembahasan dapat disimpulkan bahwa dengan media audio visual dapat meningkatkan kemampuan menyimak siswa dan daya tarik siswa terhadap pembelajaran. Hasil pembelajaran menyimak pada siklus I menunjukkan rata-rata kelas sebelum menggunakan media audio visual adalah 71.33, sedangkan sesudah menggunakan media audio visual rata-rata kelas menunjukkan 76.63. Selain siklus I, siklus II pun mengalami peningkatan yang signifikan karena penggunaan media audio visual dengan intensitas yang lebih baik lagi, terlihat dari rata-rata kelas sebelum menggunakan media audio visual menunjukkan rata-rata kelas yaitu 76.42, sedangkan sesudah menggunakan media audio visual menunjukkan rata-rata kelas yaitu 79.46. Hal ini dapat disimpulkan bahwa tujuan pembelajaran menggunakan media audio visual dalam pembelajaran menyimak dikelas tercapai.

Saran untuk guru mata pelajaran lebih memberikan pembelajaran yang menarik dalam pembelajaran, agar peserta didik lebih tertarik dan memahami pada proses pembelajaran yang dilaksanakan.

\section{DAFTAR PUSTAKA}

Arikunto, S. (2002). Prosedur Penelitian Suatu Pendekatan Praktek. Jakarta: Rineksa Cipta.

Bingol, M. A dkk. (2014). Listening comprehension difficulties encountered by students in second language learning class. Journal of Educational And Instructional Studies In The World, 4 (4), hlm 1-6
Daryanto. (2013). Media Pembelajaran. Bandung: PT Sarana Tutorial Nurani Sejahtera

Mulyani, S., \& Johar, P. (1999). Strategi Pembelajaran. Jakarta : Direktorat Jendral Pendidikan Tinggi.

Purwono., Joni., \& Yutmini., Sri. (2014). Penggunaan Media Audio-Visual Pada Mata Pelajaran Ilmu Pengetahuan Alam. Jurnal Teknologi Pendidikan Dan Pembelajaran, 2(2). 127 - 144.

Rudi., \& Cepi., Riyana. (2009). Media Pembelajaran. Bandung : Wacana

Sudjana, N., \& Rivai, A. (2007). Media Pengajaran. Bandung: Sinar Baru Algensindo

Sriwidayah. (2017). Penggunaan Media Audio Visual Untuk Meningkatkan Kemampuan Siswa Dalam Memahami Unsur Intrinsik Cerita Di Kelas Vi Sdn Jogosatru. Dwijacendekia Jurnal Riset Pedagogik. 1 (1). 84-91

Sohibun., \& Filza, Y. A. (2017). Pengembangan Media Pembelajaran Berbasis Virtual Class Berbantuan Google Drive, Jurnal Tadris: Jurnal Keguruan Dan Ilmu Tarbiyah. 02 (2). 121-129

Tarigan, D. (1991). Pendidikan Bahasa Indonesia 1. Jakarta : Depdikbud

Tarigan., H. G. (2008). Menyimak Sebagai Suatu Keterampilan Berbahasa. Bandung: Angkasa

Widyaningrum, H. K. (2016). Penggunaan Media Audio untuk Meningkatkan Kemampuan Menyimak Dongeng Anak PADA Siswa Kelas IV Sekolah Dasar. Premiere Educandum: Jurnal Pendidikan Dasar dan Pembelajaran, 5(02)

Wijayakusuma. (2009). Mengenal Penelitian. Jakarta: Bumi Aksara 